\title{
Talking Points:
}

\section{How Language Functions}

as a Status Determinant in Prison

Charles Huckelbury

Be thy intents wicked or charitable,

Thou com'st in such a questionable shape,

That I will speak to thee...

$$
\text { - William Shakespeare }
$$

Hamlet, I.iv

$\mathrm{L}$

anguage acquisition is always a part of any socialization process, whether as infants learning to speak or as adults encountering a new environment. That new environment can be something as obvious as a foreign country or as subtle as a new neighbourhood. Both, however, can be equally challenging with respect to communicating with the inhabitants.

Across this social continuum the goal is to master the local method of communication to make one's utterances intelligible and to effect a degree of assimilation that, it is hoped, will lead to acceptance by the indigenous population, or, if not acceptance, at least an absence of hostility. The formal articulation of this human ability to adapt one's innate linguistic potential to various situations grew from Noam Chomsky's (1957) seminal work, Syntactic Structures.

Chomsky (1957) elucidates a dichotomy between the intrinsic, often unconscious knowledge people have of their own language and the way in which they use the language in ordinary speech. The former, which he terms 'competence', enables people to generate all possible grammatical sentences explaining why children are able to acquire any language. Chomsky distinguishes this fundamental ability from the praxis of transforming this competence into everyday speech, which he calls 'performance'. Prior to Chomsky's work, most theories about the structure of language described only the performance aspect and were thus classified as transformational grammars.

Practical examinations of transformational grammars can of course be undertaken to provide a window into a particular culture's methods of communication. Shifting definitions, argot and non-standard sentence structure often work to describe a particular group's ethos, thereby requiring a rigorous analysis if a deeper understanding of that group is to result. 
Perhaps nowhere is this analysis more rewarding than inside the prison, where linguistic customs serve dual functions: identifying members of a particular group, and preserving that identity through the use of a stylized vocabulary and syntax.

Prisoners tend to fall into distinct categories, broadly derived from their members' previous contact with law enforcement. For those men and women who led traditional lives, that is, employment within the cultural norms of their society, imprisonment brings with it a bizarre experience that challenges both their values and, for the purposes of this discussion, their ability to communicate in a common language. A word or phrase, for example, with one connotation in the outside world can have a completely different meaning inside prison - and ignorance of this variation can be perilous.

I recall listening to a public radio station late one evening and hearing a short segment about a young gangster in East Los Angeles, who was arrested and sentenced to prison for a lengthy list of crimes. After the feature, the show's host kept referring to the gang member as a 'punk'. Unable to restrain myself, I wrote the station and explained the difference in the term as it is used outside prison, versus its more pejorative connotation inside. For those readers who do not know the difference, a punk in the outside world is usually a young person who rejects traditional values and acts egotistically with no apparent regard for the consequences. In contrast, a prison punk is someone who engages in sexual behaviour, either willingly or as a result of persuasive pressure, as distinguished from a victim of forcible rape. On the subsequent show, the host advised his listeners that he had learned something about prison and the way we use language inside.

The lesson was vividly illustrated one evening during a poker game in the block where I was living. A fresh arrival lost several hands and in his frustration called the winner a punk. Without a word, the winner leapt over the table and knocked out the man who had dared insult him. He then went to his cell, returned with a knife and proceeded to turn the unconscious victim onto his back. Straddling him, the man said, "I'll show you who's a punk". He then stabbed the man repeatedly in the chest. This is an extreme example, but it demonstrates the potential for gross misunderstanding if one does not become familiar with the language within a specific environment.

In addition to establishing a dominance hierarchy inside prison, language also serves a politicizing function, separating guards and prisoners into 
distinct factions even more effectively than their uniforms, and fostering a cohesive atmosphere that challenges any attempt at assimilation of members of one group by members of the other. The most obvious pattern is the insistence in most American facilities that prisoners use the honorific 'mr.' or 'ms.' or the individual's rank when addressing a staff member. Prisoners, however, are customarily referred to by their last names (see also Minogue, this volume), which is often prefixed by 'inmate'. The clearly political imperative distinguishes men and women who, at least in the eyes of authority figures, deserve respect from those who do not.

Professional titles are similarly proscribed in many institutions. No matter if a man or woman held a medical degree outside, mail coming into the institution generally cannot be addressed to Dr. John or Jane Doe or have the M.D. designation following the prisoner's name. Academic degrees, such as a Ph.D. or M.A., frequently result in the letter's rejection, as if prisoners surrendered their academic and professional achievements upon incarceration.

A similar feat of linguistic legerdemain determines how prisoners view themselves in response to the imposed references and how security staff view them in turn. The choices are classically 'inmate', 'convict' or 'prisoner'. The first, as Little Rock Reed (1993, p. 119) poignantly illustrates in his poem "No Neutral Ground", carries the stigma of the mentally infirm "[d]enoting diseased / psychopath receiving treatment". More recently, I hear the epithet applied to men and women whose attitudes toward security mirror those of Nazi collaborators. Among most experienced prisoners, 'inmate' is synonymous with 'snitch'. By preferentially identifying with guards and prison administrators, members of this group remove themselves from any participation in the broader prison community and advertise their vulnerability to predation by those members whose association they shun.

At the other polar extreme are the 'convicts'. This anachronistic class, shrinking each year, generally consists of men and women whose careers outside involved illicit activities and who bring those same values with them into prison. These are the cultural anarchists, respecting no authority based on privilege or custodial rank, whose self-identification harks back to an era when doing time brought with it a certain clarity and simplicity. Egocentric and predatory, they readily adopt the 'convict' sobriquet and wear it as a badge of honour, actively seeking opportunities to display their status to other prisoners or their keepers. 
These are the prison hustlers, men and women most likely to engage in edgy prison behaviour: gambling, loan sharking, drug dealing and physical violence. This group is more prone to use standard prison jargon, including the more baroque terms for prison guards: 'hack' or 'screw' in most state and federal prisons. Margo Demello (1993, p. 12) summarizes the attitudes - and the class differences - that distinguish the two groups by using the voice of a prisoner: "Fuck the world. I'm a convict, not an inmate". As Demello explains it, "[t]he difference between a convict and an inmate is respect. For the convict, after being locked up and stripped of everything he owns, respect is the one thing that cannot be taken away. An inmate has no respect. He is a model prisoner, one who bows to the authority of 'The Man"” (ibid).

Falling somewhere in the middle of this range are those who view themselves as simply 'prisoners', a collective noun that, for them, accurately describes both their social rank and their current condition. A more pragmatic approach to doing time characterizes this particular cohort, whose members tend to avoid both prison gangs and other predators as well as the traitors who spend more time in the investigator's office than they do in their cells. The Journal of Prisoners on Prisons (JPP) has standardized its references to incarcerated men and women by opting for this particular term, a neutral construction that avoids the emotional and often discriminatory baggage carried by the other two.

No matter what a particular man or woman's philosophical approach to prison might be, existential realities generally demand that he or she will adopt some aspects of prison language, including the extensive use of profanity, if for no other reason than to avoid arousing the undue attention of either peers or staff. All of us know, for example, what a shank is, and sex offenders - 'skinners' or 'rippers' in New Hampshire, for example - will continue to be objects of scorn and derision, at least in casual conversation. Failure to take the prison idiom for his or her own, even when personally offensive, marks the individual as 'other'. In the corporate world or social circles outside of prison, men and women attempt to distinguish themselves as a way of advancing. Inside prison, however, only the strongest and most determined can chart a course that ignores the pressure to conform to a code that requires surrender to a group ethos.

In what is a graphic idiomatic example, prison produces some of the most innovative permutations of the common word for sexual intercourse 
- 'fuck'. Used as a participle, it becomes a universal modifier, describing virtually everything and every activity, and the infinitive form of the verb can take on a variety of meanings, none of which are flattering. Anyone with scruples about using the term will discover them evaporating in a matter of months upon entering prison.

In considering the socializing function of speaking prison jargon, a clear analogy appears to exist between the prisoners' experiences and that of soldiers. Tim O'Brien (1986) devoted a book to the men and women who served in the United States military in Vietnam. It contained a remarkable passage explaining the callous language often used by the soldiers to describe combat and death of either their enemies or friends. These were soldiers who, like the vast majority of human beings facing an armed, hostile force, were afraid of dying but more afraid to reveal that fear to their peers. As a result, O'Brien (1986, p. 285) tells us, "[t]hey used a hard vocabulary to contain the terrible softness". This, I think, is the key to many prison vocabularies: an attempt to portray oneself as unafraid in an extremely dangerous environment by demonstrating community with others forced to share the experience, and, as O'Brien has it, to conceal a softer, more human side that would invite criticism or physical attack from that same community.

If O'Brien's analysis can be extended from the battlefield to the prison, and I think it can, then carceral language is not the "wind-swift motion of the brain" as described by Sophocles (1947), but rather a calculated choice to substitute an acquired lexicon for one's natural speech patterns. Imagine an educated man or woman entering a maximum-security prison and approaching another prisoner by offering a hand and saying, "Good afternoon. How are you doing? I've just arrived here and was wondering if you could direct me to the library, where, I'm told, the complete oeuvre of John Rawls is available". Contrast this with a curt nod and a "What up?" in passing.

An educated vocabulary projects a life not of the streets, but one of soft hands and softer Weltanschauung, a life unaccustomed to the violence that stalks every major prison. First impressions are those that most strongly resist modification, even in the face of contradictory evidence. The first approach described above thus immediately labels the person as either a naif or a poseur, neither of which contributes to peer acceptance. Even more important, the diction and the overture mark this person as weak in the sense 
that he or she is a stranger to violence as a negotiating tactic, which means predators will descend on him or her like lions on an injured gazelle.

The second interaction, however, indicates a level of experience in and awareness of the cut-and-thrust of street action, transferred to the prison environment. By adopting the language of The Life, ${ }^{1}$ the prisoner immediately defuses potential trouble by indicating his acceptance of both the vocabulary and mores of the subculture he or she has entered. This shift is thus a conspicuous example of a transformational grammar adapted to a specific environment for a political purpose: acceptance by one's peer group and, in some cases, survival. Demello (1993, p. 13) has elucidated the identical motivation with respect to the practice of tattooing in prison, where "[t]he process involves marking members as belonging to the same culture as much as it involves distinguishing members of one group from another... in a context where loyalty is often a life or death matter".

Prison is therefore a linguistic laboratory that identifies and perpetuates a specific social order, in which a descriptive grammar doubles as a prescriptive grammar. Mastering the fundamentals, along with the various nuances, defines a prisoner's status as an in-group member. Failing that task, or refusing to participate in what is often viewed as a surrender of principle, frequently brings suspicion and ostracism. The bias encountered mirrors that of the real world when someone from another country, or even a separate location in the same country, travels outside his or her traditional domain and reveals different geographical origins with the first spoken words.

If, then, humans are tribal and xenophobic by nature, atavistic tendencies rooted in our genetic heritage, prison's forced association of strangers amplifies those intrinsic dispositions, with language playing a crucial role in overcoming or, alternatively, exacerbating the regression. The techniques prisoners employ to communicate among themselves therefore largely determine the success of their social adjustment during their incarceration and in extreme cases, their very survival.

\section{ENDNOTES}

1 The ethos of contemporary life, survival of the fittest and an inversion of societal norms. 


\section{REFERENCES}

Chomsky, Noam (1957) Syntactic Structures, The Hague: Mouton.

Demello, Margo (1993) "The Convict Body: Tattooing Among Male American Prisoners", Anthropology Today, 9(6): 10-13.

O'Brien, Tim (1986) "The Things They Carried", in Shannon Ravenel (ed.), The Best American Short Stories of the Eighties, Boston: Houghton.

Reed, Little Rock (1993) "No Neutral Ground”, Journal of Prisoners on Prisons, 4(2): 119.

Sophocles (1974) The Theban Plays: King Oedipus, Oedipus at Colonus, Antigone (trans. by E. F. Watling), Harmondsworth: Penguin.

\section{About the Author}

Charles Huckelbury was sentenced to life imprisonment - 35 year minimum - at the age of 27 and has spent the last 28 years in prison. Awarded second place in Prison Life's fiction contest in 1995, he won the PEN American Center first prize for fiction in 2001. A regular contributor to the JPP since 1997, Charles joined the Editorial Board in 2001 and is now an Associate Editor. He was one of four featured writers in Shawn Thompson's Letters From Prison (Harper Collins, 2001). His new book of poetry, Tales From the Purple Penguin (BleakHouse Publishing, 2008) has received rave reviews from students and academics. 